\title{
UNDERSTANDING BYZANTIUM, by Radi Dikici (Remzi, Turkey, 2017)
}

\author{
SEDEN EREN ${ }^{1}$
}

Understanding Byzantium provides a general image of the Byzantine Empire, starting from approximately 300 A.D. (the rule of Constantine the Great) until the 1200s (rule of Manuel I Komnenos). The book briefly explains the social relationships, values and lifestyles of the society and fundamental historical incidents of the era. Moreover, it attempts to emphasize the influence of religion over governance and society. The author first published his historical research findings as newspaper articles for two-and-a-half years, and only later expanded them into a book. Therefore, Understanding Byzantium is an unusual history book which contains ten different chapters.

The Byzantine Empire, commonly known as the Eastern Roman Empire, or Byzantium, was the heir to the Roman Empire. The Byzantine Empire prevailed in the eastern territories of the Roman Empire from Late Antiquity until the Middle Ages. Even after the fall of the Western Roman Empire in the fifth century, the Byzantine Empire survived for approximately another thousand years. It fell to the Ottoman Empire in 1453.

Instead of concentrating on a shorter timeline and giving detailed information about Byzantine high society, the book attempts to provide a sketch of Byzantine society over a thousand years. Furthermore, it functions as guidance for audiences who seek to understand the basics of the inner dynamics of the Byzantines and their relationships with other countries in an easily digestible way.

The book presents readers with snapshots from over 1000 years to help visualize daily life in Byzantine, such as family structures and their lifestyles. It includes short chapters, starting from the breakup of the Roman Empire into two parts. While the author explains the historical facts, he also specifies the current geographical location of historical events and their connection to the

\footnotetext{
1 Seden Eren is a Ph.D. student at the Doctoral School of Sociology, Corvinus University of Budapest, e-mail: sseren1@yahoo.ca
} 
current era to help the reader locate the events on modern map. Due to the size of the book (216 pages), the author only gives us cherry picked, fragmented information that may stimulate the further discovery of the topics.

At the end of some chapters, based on his research, the author draws the reader's attention to incorrect historical references at historic sites. He explains the reasons behind his suggested changes and offers to help authorities reflect the historical facts better.

The chapters mostly cover the main emperors and empresses of the era. In general, the book presents us with their achievements and failures using specific examples. The decisions they made and the changes that occurred in society based on these decisions are discussed in the chapters. The author gives us his assessment of these initiatives and changes that were introduced by the rulers. The influence of these revisions and differences on society and social life are broadly argued for. In addition to this, some interesting facts about their private lives are expressed. In almost all chapters, the influence of philosophers, religious leaders, aristocrats and diplomats is plainly discernible.

Moreover, the author mentions the importance of the Byzantine universities and their impacts on society as well. A chapter called "Pandidakterion" summarizes educational life in the Byzantine Empire. Emperor Theodosius the Great (379-395) established the basis of a seven-year educational system. This was the first school system in history to introduce the idea of continuous and long-term system of learning through classical studies such as history and philosophy. At that time, the educational system could be used as a social elevator to obtain government positions within the empire. According to this system, successful students had the opportunity to be employed by the state.

The grandson of Theodosius I, Theodosius II, enhanced his grandfather's ideas and officially inaugurated the first Byzantine University in Constantinople in 425. Pandidakterion (the name of the first university) provided a wide range of educational courses, from law and architecture to medicine and engineering. In the following years, some of the graduates were promoted to the top positions in state affairs. In coming years, successful alumni played a vital role in establishing schools and universities across the Empire.

The author connects some fundamental shifts in history to the modern era. He emphasizes how the events of the past affect our society today. Especially the chapter about "Empress Theodora" is of significant importance due to its perspective on gender equality and the recognition of women's rights. According to the book, Byzantine law included articles such as women's rights and secularism which are commonly used in contemporary law. The book claims that the wife of Emperor Justinian, Empress Theodora, awarded women the right to trade, to be the legal guardians of their children, and to 
own private property. Furthermore, the death penalty was excluded from the list of punishments under family law. Although the legal commission repeatedly objected during discussions, due to pressure from Empress Theodora all articles were legalized. However, the author does not provide us with more information about changes in society or elaborate on the results of such groundbreaking changes. The author claims that the judicial system that was used in the $500 \mathrm{~s}$ in Byzantine Empire which originated in Roman law is the root of the current, modern "Western-style" judicial system.

The chapter "Corpus Juris Civilis" gives detailed information about how standardization was introduced into legal arrangements. After becoming a sovereign state, even though it inherited Roman legislation, Byzantine did not maintain the idea of one common legal system. Due to the expansion of the state and the large volume of migration, there were different interpretations of the law in each region. To establish a governing order, during Emperor Justinian's reign all laws, regulations, and decrees inherited from the Roman Empire until his time were identified and reviewed. With these new arrangements, all law departments in universities taught the same laws and all courts within the country practiced law based on these new arrangements. Thus, the legal system was merged using common ground and a unified legal system was created.

A chapter about Leo VI the Wise (886-912) proves the importance of law and the legal system in the Empire. The author claims that Leo VI was the greatest legislator after Justinian in the Byzantine Empire. During his time, "Basilika," - one of the most comprehensive legal works of the time, which covers 60 books - was completed. Later on, he ordered details of the changes initiated under his reign to be collected and published them under name "Novella." These new changes included laws related to administration, social affairs, the military and religion.

In the author's opinion, some of the prominent books and literary works of the era have effects even now - especially those books written by Emperor Constantine VII (De Administrado Imperio; De Thematibus) that give advice about how to run an Empire, foreign policy, methods of diplomacy, the geographical arrangement of countries and the legal system of empire. Besides writing his own books, he supported many literary initiatives in his era in order to promote and spread scientific and cultural knowledge. With the guidance of these books, audiences today can obtain more detailed information about the empire, its relationship with its neighbors, and its history.

The book also provides a snapshot of how the different dynasties changed during the given time period. Furthermore, it explains how the power handovers between the dynasties. With the examples and cases that are provided, audiences are able to perceive the influence of the architectural, legal and social activities 
of these various dynasties on society. In addition to this, changing international relations and political movements based on the changes of dynasties are discussed.

Although the chapters inform the audience about the Byzantine Empire, some questions remain unanswered. The chapter "Crux Vera" promotes the author's research findings about the "Holy Cross" myth. As a matter of fact, in this chapter the author points out the potential current location of the Holy Cross. His arguments have attracted the attention of Orthodox Churches in many countries. Some Greek, Serbian, Montenegrin and Romanian media have paid significant attention to this information. The author mentions some other theories as well, but the current location of the Crux Vera is still a question mark.

The Halki (Heybeliada) Seminary chapter highlights a fundamental issue in the contemporary international relations of Turkey. The Halki Seminary was established by Patriarch Photius I in 878 as an Orthodox monastery. Approximately a thousand years later, the Theological School of Halki was founded on the same site in 1844 . The school provided theological education until 1971 (except for a short break during World War I) and was considered one of the top theological schools. The seminary had around 900 alumni, the majority of whom became Orthodox patriarchs, bishops and priests. Halki Seminary was a theological school which had an international reputation in its field and welcomed Orthodox Christian students from all around the world.

In 1971, the Constitutional Court of Turkey ruled that all private higher education institutions should be affiliated with state universities. After this decision, the seminary was closed down. The issue of Halki Seminary is a sensitive subject which has attracted the attention of leaders in the United States and the European Union. There have been many discussions about how to re-open the school, but the seminary currently remains closed. To reach a mutually acceptable conclusion for all sides, the author suggests agreeing on new legal regulation that would result in the re-opening of the seminary in the foreseeable future.

In spite of some restrictions due to the long period of time, the density of the incidents and information, the book highlights cherry picked but crucial historical facts about the Byzantine Empire between 300 A.D. and the 1200s. It is therefore an instructive and significant book which should increase understanding about one of the biggest and most influential empires in history. The book covers many of the latest findings about the Byzantine Empire. Accordingly, reading this book is essential to understanding the influence of history on the present world. The book may be useful for an audience who would like to obtain a quick, high-level overview of the rise and existence of the Byzantine Empire in an entertaining way without being overwhelmed by academic jargon. 
Understanding Byzantium paints a general picture of the changing situations and circumstances through a historical perspective. The author presents written historical documents, agreement and codes as evidence to support his findings. The language which is used in the book is understandable, although the reason for the division of the chapters is less clear. Some chapters are clearly separated according to specific eras in time, while some chapters cover longer time periods. In fact, while some chapters are clearly dedicated to one event, others compare history to current conditions. Despite this, audiences might still be inspired by reading the different articles in each chapter rather than by reading a comprehensive book. However, for this reason, in some cases it is not easy for the audience to connect the chapters and fully understand the book.

The author prefers to use extensively simplified terminology to ease the process of understanding the information he introduces. He has the ability to present historical subjects in a mystical and mysterious way in order to grab the attention of audiences outside of the academic community. Furthermore, he supports the context with pictures, illustrations, and blueprints. This approach helps the audience to visualize and grasp the content of the chapters from the relevant historical perspective.

The author Radi Dikici is a Turkish researcher, known for his research, articles and books about the history of the Roman and Byzantine Empire. So far, he has published 15 books, mostly in Turkish, and mainly about Byzantine history. This book ought to be very useful and helpful to those people who are interested in the subject, while it should also reach different audiences in different countries. 
